\title{
Article \\ And G-d Created Wife: How Did the Modern Other Emerge? **
}

\author{
Sergey Dolgopolski
}

check for

updates

Citation: Dolgopolski, Sergey. 2021. And G-d Created Wife: How Did the Modern Other Emerge? Religions 12: 863. https://doi.org/10.3390/ rel12100863

Academic Editor: Richard A. Cohen

Received: 30 August 2021

Accepted: 6 October 2021

Published: 12 October 2021

Publisher's Note: MDPI stays neutral with regard to jurisdictional claims in published maps and institutional affiliations.

Copyright: (c) 2021 by the author. Licensee MDPI, Basel, Switzerland. This article is an open access article distributed under the terms and conditions of the Creative Commons Attribution (CC BY) license (https:// creativecommons.org/licenses/by/ $4.0 /)$.
Departments of Jewish Thought and Comparative Literature, University at Buffalo, SUNY, Buffalo, NY 14260, USA; sergey@buffalo.edu

** For Elen-Sarrah and Marc, in no particular order.

\begin{abstract}
Asking the question of the emergence of the modern other, the paper explores the inversion of relationships between wife and woman, husband and man in an archeological analysis of a Talmudic reading by Emmanuel Levinas "And God Created Woman." The theoretical framework of inquiry focuses on the development of relationships between the human on the one hand and the thinking and acting subject on the other. The guiding question is that of defining modern subjectivity by the disappearance of rabbinic discourse from its horizon.
\end{abstract}

Keywords: modern other; woman; wife; human; modern subjectivity; rabbinic literature; philosophical archeology; memory of the present; evolution of subjectivity

\section{Introduction}

When and how did the modern other emerge? This would be the other of the modern subject; the modern human being. An accepted view is that the modern subject is Cartesian; the modern notion of the human being is Kantian; the critique of the resulting notion of the "human subject" as the subject-agent is Nietzschean, Heideggerian, Derridean, Foucauldian, feminist, and poststructuralist; the primary responsibility of the human subject to the other is Levinasian; and the Talmud was there all along when these modern critiques of the human subject arrived. For this accepted picture (and for the respective other this picture implies), the work of Alain de Libera provides either a critique or an opportunity for one. Libera does so by reclaiming the suppressed role of philosophical work in the seemingly purely theological corpora of the church fathers and medieval schoolmen. This hitherto overlooked work is the bedrock of the notions of the human being and of the relationship between humanity and subjectivity, he argues. Omitting this bedrock from the view creates a distorted picture above. The changed picture of the emergence of humanity, subjectivity, and otherness changes the theoretical framework of discussing their modern manifestations in the above modern thinkers, as well. It further leads to the task of rethinking the modern scholarship on the Talmud, predicated as it has been on modern subjectivity as the self-understanding of the Talmud researchers. It is in this context that the present essay asks the question of the emergence of the other in the modern philosophical discourse on the Talmud, focusing on Emmanuel Levinas as the leading thinker of the last century to combine the inquiry into the Talmud with the inquiry into the other. How the modern other emerged thus becomes a guiding question in reevaluating not only Levinas's Talmud, but also, and more importantly, the rabbinic thought, of which the Talmud is a central text, on the intellectual map of the West. ${ }^{1}$

\section{Results}

A philosophical position of Levinas as a reader and interpreter of the Talmud cannot be false, yet its truth is to be defined by the context of modern subjectivity and the modern human subject, against which Levinas both reads the Talmud and advances his ethics of responsibility toward the other. Modern subjectivity features a reversal in relationships between wife and woman, husband and man as versions of human subjects. The subjectivity and humanity in Talmudic discussion reaches beyond and before the horizon of modern 
subjectivity. This opens up the double question of how to read the Talmud beyond that horizon of human subjectivity and otherness, and how to situate the modern and medieval notions of otherness and femininity in the broader context of the history of thought.

\section{Discussion}

Just as Emmanuel Levinas began a "Talmudic reading" by stipulating that he was not an "absolute Talmudist," so too I begin by stipulating that I am not a Levinas scholar; and that my interest in Levinas as a reader of the Talmud arises primarily from my interest in rabbinic literature as a mode and way of thought in the broader context of the intellectual map of the West. Levinas's importance for me is first of all in that he created a very important modern opening into exploring rabbinic literature and philosophy relationships to one another as disciplines of thought and modes of action. ${ }^{2}$ In what follows, I propose an archeology pertaining to Levinas's Talmudic reading "And God Created Woman." I evoke the archeological method as it is understood by Alain de Libera, an heir and critical scholar of Heidegger's and Foucault's ways of thinking about the beginnings or archai in history of thought, of which rabbinic thought is a yet not sufficiently reclaimed part.

In Annette Aronowitz's translation, Levinas begins the reading as follows:

"The text will speak to us of wife [la femme]. It opens with three statements which concern the human [humain] apart from its division into masculine and feminine. From the start, the text is concerned with a certain duality in the human being [homme] and with an attempt to define what the human is." (Aronowicz et al. 2019)

In this translation, I make only one emendation. I emend the translation of la femme as "woman" by "wife." My argument below will explain why the emendation is heuristically important and what powers are working against it, in both traditionalist and modern thought about the relationships between wife, woman, and the humanity of the human.

I would like to ask first, what exactly is a "Talmudic Reading", in Levinas's sense? Is that a reading in the Talmud? Is it a reading of a philosophical question (in this case the question of humanity of a human) talmudically? Is it a reading of the Talmud philosophically, that is to say, in the optics of a philosopher rather than a theologian? To answer these questions is to isolate the question his "Talmudic" readings are answering. If, as Levinas's other texts are suggesting, his question is how to reach beyond, or how to recognize the beyond of the human subject, then archeological questions need to be asked: which subject are we talking about and in which sense do "subject" and "human" come together to form what today is an obvious, perhaps too obvious, notion, that of a "human subject." Agreeing with the argument of Alain de Libera on the archeology of the modern thinking subject, I assume that the subject beyond which/whom Levinas is philosophically advancing is a subject, who acts, thinks, wills, desires, and speaks; or at least a subject who thinks that action, willing, desiring, and speaking are her properties; even more specifically, that subject thinks that willing, desiring, and speaking are actions, and that these actions are properties of, or are attributable both logically and ethically to, that subject.

Any "decentering," any reaching "beyond the subject," de Libera argues, needs an archeological context to show how, when, and where the subject-agent, the thinking, willing, desiring, and speaking subject, takes shape historically in the first place. Unlike his teacher, Foucault, and unlike Foucault's teacher, Heidegger of the mid-thirties, De Libera (De Libera 2011, 2015) answers that the modern notion of a thinking subject is not an invention of Descartes, and the modern notion of a human is not an invention of Kant, but that both are versions of medieval attempts to reconcile incompatible versions of Augustinian positions in which mind, mens, can be attributed to no subject with versions of Aristotelianism, in which Aristotle's notion of hupokeimenon (or its Latin equivalent, subiectum, as that which lies before or under, and is neither active nor passive) becomes reinterpreted as able to act and as acting, resulted in an eclectic, but now regnant notion of a subject-agent who thinks. In this context, de Libera further argues, the modern notion of a human as such a subject-agent is a reworking of the Augustinian notion of a human as a mens or mind that 
can belong to no subject at all, and which is a side in which the human and the divine that meet as both are mens.

Because of the importance of the other in Levinas's philosophy and in his Talmudic readings alike, one instance of the history of the conflation between Aristotelianism and Augustinianism is specifically pertinent. This is a version in which the idea of the recognition of the other person as also being a speaking and therefore thinking, acting, and suffering subject takes shape. This version has to do with the Franciscan Peter John Olivi (1248-1298), who argued that my recognition of the other person is based on the notion of inner experiment or inner experience- on the notion of an intuition of myself, because to know something also means to know that I know that I have an immediate intuition of myself, Olivi argues; and if I am both speaking and have such an intuition of myself, anybody else who speaks (no matter how this anybody is looking) must by inference must have an immediate intuition of oneself, as well. This is why and this is how, a face that speaks must be the face of someone who is acting and suffering, and willing, and thinking, and knowing - just as I do.

In his critique of the totalizing and therefore (paradoxically) limiting embrace of the human subject, Levinas responds to the question of how to reach beyond that sense of the other. That also means that-as the starting point-he assumes that sense of the other as the face that speaks and therefore thinks, suffers, and has inner intuition of oneself. He is an Olivian in that sense. Yet, as de Libera argues, just as Olivi runs an intrinsically ambivalent combination of the un-combinable positions of Augustinianism (mens, mind can belong to no one) and of Aristotelianism (mind belongs to the subject-agent (I know and therefore I know that I am the one who knows)), so too is Levinas's response ambivalent to the totalizing powers of the thinking subject.

This ambivalence finds an expression as a tension between Paul Ricoeur's and John Llewelyn's interpretations of Levinas. For Ricoeur, a given is "the beautiful analyzes of the Jewish philosopher Emmanuel Lévinas on the face." (Ricœur 1984) "Each face is the Sinai from which [there] proceeds the voice that forbids murder." This voice, Ricouer argues, is G-d's direct speech to me, so that the speaking face of the other person is the speaking face of G-d. By killing the other person, you are killing me, G-d, Ricouer understands. For Llewelyn (Llewelyn 1991), by contrast, the face of the other does not exactly speak. Instead, the "do not kill" is the "divine" inscription I read in the face of the other, as long as I-despite my will-face the face of the other. For Llewelyn, that paradoxically means that the other person does not have a say, and that the face of a non-speaking but barking dog equals to the face of a speaking human, as long as I face them as faces, i.e., as long as I read the inscription "you shall not kill" thereupon. The face and the inscription "you shall not kill" on it, is a given, when and as long as I am sure I am facing a face. In turn, the "you shall not kill" is not surely given when I am not sure; for example, with Levinas's analysis of facing a snake, where he said he was not sure if a snake has a face. (Ironically, the Biblical snake spoke, and thus had a face, an Olivian would have argued - with much more certitude than Levinas's sense of responsibility allows.) Yet, that concern with Bobby the dog for not having a say is Olivian without any irony, for the concession that the human and the dog equally do not have a say is what Llewelyn criticizes Levinas for. Of course, on either interpretation, Levinas's philosophical position cannot be wrong. Whether the face effectively speaks or only speaks (in words or in barks) without having a say, it is the face of the other, who suffers, thinks, wills, or even, on Llewelyn's reading, becomes completely deprived of speaking effectively, and the face is still surely attempting to speak.

However differently Ricouer and Llewelyn interpret Levinas's position, and however strong may be the duality of his thought that they collectively express, this duality between speech and inscription on the face of the other arguably remains within an Olivian horizon; the face of the other is the face of the one who is at least potentially able to speak, and therefore-so the argument goes-has inner experience. The other, therefore, is the subject-agent, who thinks, wills, knows, etc., either probably (a dog) or surely (a human). On either reading, the (speaking) face of the other defers to $G-d$, the immediate intuition of 
whom is given to Olivi in "my" immediate intuition of myself as the subject of my knowing, thinking, suffering, etc. That immediate intuition, however, remains to be posited as that of G-d who is neither my nor anybody else's property.

As these differing interpretations of Levinas show, such an Olivian duality of the Augustinian version of a person who does not possess thinking and the Aristotelian versions of a subject-person who-putatively - has thinking as a property and thus "thinks" remains at work in Levinas, as well. The same duality is also at work in another commentator of the Biblical creation of the woman, Rashi (1040-1105), who, as I will show below, can be called - almost - an Olivian, or belonging to a horizon of thought which Olivi represents. My stipulation "almost" will have to do with what I will present as the key element of Rashi's position, his differing sense of the first other as gendered in its core. More specifically, in Rashi's position, on my reading at least, the matter concerns the primacy of the woman as the original other. That will further have to do with the primacy of the wife to both her husband and to the woman, whom, as the wife is afraid, he can marry when the wife dies.

My point of departure here is Rashi's commentary on the Biblical text:

"Additionally, she gives it to her husband" (Gen 3:6) - lest she dies and he lives, and he marries the other (ותתן גם לאישה שלא תמות היא ויחיה הוא וישא אחרת)" (Rashi, 1040-1105, ad locum)

Facing the prospect of death, the first wife offers her husband to eat the fruit in order to prevent him from marrying the other. Read in the modern context, this 11th century gloss opens up what today might seem a rather unusual, indeed new, perspective on gender and sex relationships. In the first approximation, Rashi's gloss contravenes the hitherto prevalent view of the figures and concepts of man and woman (however defined) as primary and generic, and of husband and wife (however defined) as secondary and specific.

Rashi's commentary is on the fragment of the verse Gen 3:6, which reads in Robert Alter translation as follows:

"Additionally, the woman saw that the tree was good for eating and it was lust to the eyes and the tree was lovely to look at, and she took of its fruit and ate, and she also gave to her man, and he ate" (Alter 1996)

To gloss further what does not quite make it into any given translation: the other (אחרת) is feminine-a sense the English is not equipped to convey, except for a rather artificial "she-other." A less smooth translation could be more helpful for the purposes of this analysis: " . . lest she dies and he lives-on and he marries the other of her." Who is "the other of her?" Who is that, grammatically speaking? Who (and not what) is that other feminine? This question needs to be answered as a who-question, not as a what-question; in other words, not by a classificatory statement.

To gloss even further is to highlight a tacit but not quite certain choice: after we established the femininity of that "other," the choice between "the other" and "another" remains: who is that "feminine other of her"? A person her husband can marry after wife's death? The person of that sort, the wife already having in mind? One is sure: the wife is trying to prevent her husband from marrying again after the wife's death. One other element is even more clear: the grammatically feminine other is the woman, the one who is marriageable to the wife's husband.

One last step will take us even closer to the point Rashi's commentary suggests. His gloss has to do with another word, "אישה", which Alter renders as "her man." A wellconceived ambiguity of that rendition, "man" as both "a man" and "the husband", would need a more explicit articulation and more careful thinking through. That will help to isolate a point in Rashi's commentary. In the order of presentation in Genesis, a reader, or at least, this reader, moves from the creation of Heaven and Earth to making Adam (1:26), "a human to till the soil" (2:5; Alter) "the human, humus from the soil (adama)" (2:6; Alter), to "building the rib" the Lord "has taken from the human into a woman" (2:22; Alter), to a meta-explanation "Therefore, does a man leave his father and his mother and cling to his 
wife and they become one flesh" (2:24; Alter). Notably, in this meta-gloss, Alter switches from having translated was "woman" so far, to a new translation as "wife." Next in the sequence, she gives the fruit "to her man" (sic) (3:6; Alter).

If the Bible's readers disallow switching terms in translation, they would find themselves following a movement from the void earth, to humus of the soil, to making human out of the humus, to "building" a wife (אשה) out of the human, and on to the wife rendering the human her husband (אישה). From Adam to Isha, to Ish; that is, conceptually, from human out of humus or soil, to wife, to husband. This is where Rashi's commentary intervenes, signaling the birth of another-wife-who-is-not-wife-yet, but can become a wife if the wife dies. In a sense, which is rather different from Alter's rendition, Rashi's commentary locates the first emergence of a woman in the Bible: someone the husband would "marry" (Rashi) if his wife dies. Woman, on that scheme of things is thus someone not-married yet, but who is marriageable.

Woman, in other words, is a specter of the wife's death; the first specter (one can say of jealousy) caused by the first wife's fear of death. Interpretations of the feelings arising from the first wife's fear of dying alone, with her husband to continue to live on, can vary. Yet, the sequence of production remains the same: from Adam (human) to wife, to husband, to woman, and only then to man. In that sequence, "man" comes right after and as a by-product of the "woman"; we advance from the "woman" as a marriageable person to become a wife to a "man" as a marriageable person to become a husband. In less precise but more convenient terms, the sequence ${ }^{3}$ unfolds from Adam, to wife, to husband, to woman, to man.

This conceptual sequence of becoming is the opposite to what dominates society after the first wife and her husband had children. As reflected in the Biblical meta-commentary, "Therefore, does a man leave his father and his mother and cling to his wife" (Gen 1:24, Alter). In generations after the first wife and her husband, a metalepsis of cause and effect occurs. Instead of woman being a product of the wife's fear of death, a "wife" becomes a role for a woman either to assume or to refuse. From woman being a function and fiction produced by the wife, a wife becomes a function of woman.

The laconic commentary by Rashi thus has far-reaching implications. It suggests no less than the primacy of a wife over a woman and of the husband over the man. It also suggests that the subsequent generations live in metaleptic reversal: man and woman are primary, and wife and husband secondary. The implications of this critical insight on gender relationships are hard to overestimate. Marriage is now the default condition of Adam, rather than a mixture of initially separate elements. This view reaches much further than an idea of soul-mates, and even further than the trop of androgyn can afford. Both soul-mates and androgyn presume a mixture of pre-given concepts, while what Rashi's commentary spells out is not an initial mixture followed by separation to compensate for by reunion. Rather, a production of husband has been induced by the production of wife from the human, the Adam. The latter, of course, can no longer be rendered with the all too ambiguous "man", for the word fails to differentiate the cause and effect, let alone to articulate their order, which is either the direct conceptual order from wife to husband to woman to man, or the historically inverted (and more familiar) order from man to husband and from woman to wife.

Rashi thus contravenes or inverts the modern view, in which men become husbands and women become wives, while still remaining what they were before, men and womenindependently from the marriage. In that modern view, "husband" or "wife" only characterize the relationship of a man or a woman to their respective partner, just as their relationships to their children position them as mothers and fathers. Yet, in their core gender they remain a man or woman. Conversely, both logically and chronologically, in Rashi's commentary, there first emerges a wife, then there comes her husband, and only then, in the imagination of the wife, who fathoms her death, a specter of woman looms in. From then on, not mentioned in the commentary, but available for its readers, there emerges another specter, another extension of her phantasm - the phantasm of (another) man, or a 
man in general. In this scheme of things, woman is the first other, and it is the other the wife creates and deals with by offering her husband the fruit.

To address the relationship between Rashi's inversion, and the modern medical gaze: A modern medical gaze sees a spectrum, rather than two sharply defined sexes. Modern gender theories also see a spectrum of gender roles, as independent as they proved to be of the spectrum of sexes. Yet, the two traditional normative poles, and thus the defining terms of both spectra, remain the same: the man or male on the one hand, and the woman or female on the other, for sexes and for genders, respectively. However fluid the pairings of man, males, husbands, and women, females and wives can be in that view, husbands and wives remain to be no more, but also no less than parts of the broader spectrum of gender roles. Performing a husband or performing a wife is only a part of other gender performances, nor the most general let alone generative notions.

In sum, according to Rashi's commentary, both logically and chronologically the first "other" in the Bible is woman. ${ }^{4}$ She is a phantasm of the first wife, as the wife faces the prospect of death. Adam does not call his wife "other." On the contrary, Adam finds the wife the closest to him, for she makes Adam husband. Who then is a species and who is a gender-a man or a husband? The same question applies to the woman and the wife. Who comes first? Do women become wives and do men become husbands? These questions are general and thus concern genders, not sexes (for sexes are always individual, medically determined by application of a general to the individual.) What comes first - a woman or a wife, a man or a husband?

The answer is obvious, in the modern days: husbands emerge from man and wives from women. This obviousness remains, even if one supports and performs gender fluidity; it always goes in one direction: from a man (or a woman) to a husband and from a woman (or a man) to a wife. Yet, the obvious needs to be questioned as such, that is to say, a limit to the obvious needs to be found, at which the obvious ends, and Rashi's commentary helps to find the limit of the obvious, without, however, either undermining the obvious or explaining what makes the obvious ... obvious.

The question becomes, what then defines, archeologically, both Rashi's view of "the other of her" and its reversal in modern gender relationships? A connection between Rashi and Olivi can help with that question: both Rashi's and the modern sense of the relationship (i.e., of the primacy and derivation) between man and husband, wife and woman are predicated on Olivi's explanation of the emergence of the other by inference from the sense of my immediate intuition of my own thinking and my own speaking, from which, by inference from observing the speaking faces, I conclude that they are the others, who must also have such an immediate intuition of themselves as thinking, acting, willing, suffering, and yes, marrying subjects.

The Olivian horizon thus allows moving in both directions of inferring the other, that is to say, of the woman, either in the initial move from wife to woman or in the reverse, from woman to wife. The reversal is no less and perhaps even more powerful than the original inference, and Levinas, in his reading of the Talmud, seems to remain within that reversal, so that the expression of the original-and as we will see, the holistic duality in the human - will find an expression as masculine and feminine, man and woman - which in both cases reveals, or by Ricouer's interpretation at least, "the other in me" - the duality and the otherness is in me-a move both Rashi and its modern reversal support.

I would like to explore the sway and the scope of this historic reversal further; to see how far the powers of the primacy of the wife before husband, woman, or man are reaching archeologically. To the best of my knowledge, in the prevalent readings of the Bible, except for this commentary of Rashi, the reversal is lost from sight, and the memory of it is entirely lost. Yet, it cannot be forgotten either. In the following reading of a Talmudic discussion in b.Brachot 61a, I will highlight the perhaps non-remembered but surely unforgettable powers of the primary production of woman from wife. To discern these powers, we will have to undo the Olivian, or for that matter, any other combination of Augustinianism 
with Aristotelianism; and to reclaim a Talmudic parallel of Augustinian mens (mind) as belonging to no-one, i.e., to no thinking, willing, or acting subject.

In this analysis, I will only be able to do so on a short example, which I precede with a theoretical overview of its larger result. The example will have to do with a text from the Talmud, which Levinas read for the otherness in the content of human thought, and which I will read for the subjectlessness of that thought as a version of mens.

Levinas reads the Talmudic text for the primary duality in the human, for the other within, well before woman is even discussed. He also reads for the humanity as the "end of interiority" (the opposite of Olivi, that is to say). The feminine does not derive from Ish; rather, the dichotomy derives from what is human, he argues. Levinas is reading for the duality in the human subject, to which only then the difference between male and female and man and woman is ascribed as the difference from within, the interiority which is exteriority, the move beyond the monolith human as subject and the subject as human.

By contrast, as I will attempt to show, the rabbis argue for memory but not for any connection between the human and the subject, and for much richer and less inner-split plurality within subjectless mens (mind,) than just for a duality within human subject. I can only say in advance that like Augustine, the rabbis entertain the then new concept of a human as a who, that is to say, as a question without answer; a who is thus not a subject in either the Aristotelian sense of hupokeimenon, nor in the latter sense of the subjectagent. Mens, Augustine argued, is the memory of the present (Margel 2015), that is to say, the memory of the who, who is present but possesses nothing, no attributes whatsoevera who, who is not a what. Unlike Augustine, however, they emphasized not only the memory of the present but also the impossibility to forget the past, even if the past yields no satisfactory memory or remembrance. This impossibility to forget the past, which cannot be remembered, produces the multiplicity of the main mens on the stage of the Talmud, the mens as the remembering, i.e., as supporting the mutual exclusivity of specific memoirs or dicta or interpretations marked by the names of the masters of previous generations.

The question thus is not that of duality in the human subject, of which man and woman are parts or expressions, but that of maintaining and defending multiple and mutually exclusive remembrances of that which can be neither forgotten nor remembered in one and only one definitive way.

As an example, I take what opens the page of the Talmud before Levinas and Rashi (and Olivi, if he read it) alike.

The text is from bBerachot 61a; it is a polemical exchange between or on behalf of two rabbis arguing about a duplication of a letter in the spelling of "formed" in Genesis 2:7 "Additionally, the G-d Lord formed the human." The question is why does the verse spell out "forming" with two of the letter yod.

Rabbi A (Rabbi Nachman bar Rav Hisda) posited: duplication of the letter yod (in Genesis 2:7) must mean the human was formed with two innate natures-the evil and the good.

Rabbi B (Rabbi Nachman bar Itzchak) objected: However, the Bible spells out the "forming" of wild animals of the field with only one letter yod, even if we observe the animals of the field to cause damages (which implies evil nature without good nature!) Rather, the duplication means no duality in human nature, but an impossible position of a human between the Creator and the evil nature, which would be in accordance with Rabbi C (Rabbi Shimon bar Pazi,), as C said: Alas to me because of my Creator (lit: because of my "former") and alas to me because of my nature (lit: because of my formation)! A nameless rabbi, D, offers another outcome of $\mathbf{B}^{\prime}$ 's attack, or rather, the duplication of the letter could be explained in accordance with Rabbi E (Rabbi Jeremiah ben Elazar), as E said "The Holy one, Blessed be He created the first human of two faces, as it says (in the Psalms 139:5) "You hedge me (lit. "press me" or "form me") before and behind."

For A, human nature as a whole has a duality. B reduces the two natures theory to absurdity: it implies that animals either have two natures as well, or there is only one nature in the human and in the animal alike: the evil. Instead, B recognizes that by nature, 
humans and animals alike are evil, yet unlike other animals, humans are also cognizant of the goodness of G-d and, in accordance with C, the humans are trapped between the goodness of G-d on one hand and the evil of their own nature on the other. For D, a recollection of $\mathbf{E}$ offers another way to avoid absurdity: the two letters mean neither two natures (=good and evil) nor one nature (=evil) of the human; instead, the human was created with two forms, or two faces - one facing ahead and another backwards.

Levinas reads $\mathbf{A}$ as advocating for differences within a whole: the human is first of all a whole with innate duality without a closure. Unlike the position Levinas cautiously ascribed to Jankelevich, the human is not a mutually complementary combination of either male and female or man and woman. Rather, the differentiation in the whole is primary, and the differentiation between male and female or man and woman is secondary, he argues. Isha (or as he understands it, the woman) comes from the Ish (or as he understands it, the human). He further reads $\mathbf{B}$ through $\mathbf{C}$ as refinements of the holism of the $\mathbf{A}$. As a result, $\mathbf{D}$ becomes a refined version of $\mathbf{A}$. To wit:

"However, there is something else in the parable of the second[, other] face. Woman is not at issue yet. The feminine face will appear later, starting with this idea of "continuous face," which at the outset signifies the sheer humanity of man. The meaning of the feminine will thus become clear against the background of a human essence, the Isha from the Ish. The feminine does not derive from the masculine; rather the division into feminine and masculinethe dichotomy-derives from what is human. Complementarity [of man and woman] has no concrete significance, is only a lazy turn of phrase, if one has not previously grasped, in the idea of the whole, the necessity and the sense of the division. I am not sure that our friend Jankelevitch wanted to express more than the formal notion of complementarity when he talked about interlockedness." (Aronowicz et al. 2019)

Levinas thus advocates for a differentiation within the initially given holism of the human nature; he argues against the innate nature of the female-male divide, and thus against complementarity, if that latter loses the initial holism from the view. In order to advocate for the holism of $\mathrm{A}$, Levinas reads $\mathbf{D}$ as a more articulated version of the holism of $\mathbf{A}$, and to do so, he reads all positions $\mathrm{A}$ through $\mathrm{D}$ as unfolding one and the same view on the essence of the human; the nature of the human is not strictly speaking anything natural, it is two faces of the same human: one looks backwards at the goodness of the Creator and the other grasps for the good while looking ahead to the calamities creation brings forth.

Such a reading of $\mathbf{A}$ through $\mathbf{E}$ as articulating, step by step, one and the same position of holism, preceding both differentiation and complementarity (interlockedness) and ending up to be a holism of human to have always reached "beyond the [human=] subject", is in line with the longstanding tradition of reading rabbinic texts as medieval tractates which always mean to present a winning position and to deliver it to the addressee, typically to a student or apprentice. Levinas, in this respect, is a more traditional Talmudist than he was willing to admit in his recurring remarks of being "not an absolute Talmudist" or only an "amateur Talmudist." In reading the Talmud as a tractate, and in particular of this composition as a mini-tractate with one winning voice, he is a rather traditional reader of the Talmud. In other words, his reading is true to its hidden assumption that the positions $\mathbf{A}$ through $\mathbf{E}$ are steps in working out one privileged position for the addressee to assume.

Yet, the composition in front of us can be even more polemical that the unifying form a tractate can afford. B can be seen as advocating for only one inclination, the evil one (a trope often found in the Talmud elsewhere), and C as offering a mereology which is not exactly holism. If holism assumes differentiation within the whole (organic whole in Goethe and Hegel, for another example), the mereology of $\mathbf{C}$ is that of the human facing the impossible choice between the good and the will of the Creator and the evil inclination which creation is advocating by always persuading the human that in his/her actions or 
thought s/he can never mean evildoing (a position for which Augustin is another example). In this mereology, the holism is that of agon, of standing between God/good and evil, an agon in which there is no inner differentiation, only the standing in the agon, a stand in which the human is not divided from within, for there is no within, or as Levinas has it, "the end of interiority" - as if the interiority were given from the get go.

Of course, the interiority is given, if one polemically starts, as does Levinas, from the human subject, whom he is arguing to take beyond the subject. Archeologically, this interiority is Olivian, but it is not necessarily in the rabbis, if we do not read them as characters in a tractate. Levinas can thus not be wrong, yet the truth of his analysis is ... well ... true to the post-Olivian situation in which he correctly calls us to open our thinking to the beyond of the subject. Yet, if no longer treated as characters in a tractate, the rabbis are thinking in ways that are closer to Augustine: thinking can belong to no one, to no subject at all, and it is this no-one who (the who, who can never be defined by an answer in the form of a what) thinks through polemical engagements, refutations, and counterrefutations that the moves from $\mathbf{A}$ to $\mathbf{E}$ represent. Therefore, there is no need to go beyond the subject, for it is not a subject, who thinks, acts, or wills.

A case of such change in perspective on Talmudic compositions as no longer medieval tractates would be a view, which, paradoxically, arises from Rashi's commentary on the creation of the wife: The wife creates a woman, and thereupon also a man; there is no whole, only an unfolding of a human to a wife, to a husband, to a woman - as the first other ever. It further moves to a man - an unfolding which, as discussed above, is becoming lost or reversed in the world of holistic dualities in which Levinas polemically operates, when he successfully disentangles the distinction between male and female, or man and woman from being the foundational distinctions in answering the question of who a human is. If this essay accounted for this reversal and for what is being lost behind either modernday holism or that reversal alike, i.e., for the rabbinic thinking of "Who?" for which there comes no "What" as an answer, this essay did what it was intended to do.

\section{Material and Methods}

The main methodological framework of this research is philosophical archeology, as well as methods of textual interpretation and analysis in rabbinics. The materials have been introduced in the course of discussion.

\section{Conclusions}

To conclude, as a philosopher, Levinas cannot be wrong in critiquing the monolithic human subject, yet the truth of his critique can only be understood and valued properly within the polemical horizon around the notion of a human-acting, thinking, willing, speaking, and suffering-subject. ${ }^{5}$ This is a horizon, of which the rabbis in the Talmud show the limit: precisely at a point at which they disappear from view, a point at which the joint of the human and the subject - the thinking, the willing, and the speaking humandisconnects from the mind or mens (human and divine alike), which belongs to no subject at all.

The essay's conclusion, that a Biblical-Talmudic anthropology grounds a different (and currently vanishing) perspective on the human than the modern Olivian one, leads to a broader question. This question regards which discussions in the Talmud embody and/or originate such anthropology, which also invites and even demands us to think more broadly about the significance of that vanishing anthropology for understanding the ends of the other today.

Funding: This research received no external funding.

Institutional Review Board Statement: Not applicable.

Acknowledgments: I would like to recognize the support of Gordon and Gretchen Gross Professorship in Jewish Thought at the University at Buffalo, SUNY. 
Conflicts of Interest: The author declares no conflict of interests.

\section{Notes}

1 In method, this essay is a version of archeology. I read bodies of texts and thought for difference rather than continuity; that means for limits, originary foundations, beginnings, or archai (hence archeology) that emerge and disappear in the traditions of thought and in how these traditions think and rethink their foundations. I address Levinas's thought in his reading of the Talmud against the horizon of modern subjectivity and otherness - in differentiation from the Talmudic thought as disappearing from that horizon. By way of a negative comparison, a distinction between the history of philosophy and philosophy would not necessarily apply to an archeological work, which can be approximated as thought in the sense of probing its constantly evolving beginnings.

2 For the most recent analysis of the place of "Talmudic readings" in Levinas's trajectory as a philosopher, see (Lapidot 2021).

3 That sequence is of course only meaningful, if, together with the Medieval commentators, one assumes the Biblical text has a form of tractate, in the sense of an internally consistent letter, however long, to the student from the master-a letter that therefore must always be consisent not only in what it says but also in the order in which the saying proceeds. Such a reading of the Bible would therefore be medieval in form, too.

4 This should not be confused with a modern feminist critique of positing the woman as the other. While the claim looks similar, it comes within a rather different polemical context. If such a critique targets othering the woman, who on the contrary should not be treated as other, then in the world of Rashi's commentary the other is a creation of the first wife; it is the other of the wife, the specter of the other wife, which is far from being the same as woman in any modern sense, in which woman is set as primary and only then is - unjustly - othered out, let alone objectified.

5 One might ask, what does the analysis in this essay mean for a feminist reading of Levinas? An answer would be that it can help reframe the question of the relationship between the feminine and masculine in the human, in an archeological way. That would mean to situate a future analysis of the mereology of the wife and the husband, woman and man, in their mutually subverting medieval and modern orders within an archeological differentiation. Preliminarily, such an archeological differentiation would be between (1) modern mereology of the extensive (or call it exterior) whole of the human being after Levinas versus the Olivian intensive (or call interior) whole of recognizing the subjectivity of the other face on the one hand and (2) the Augustinian mereology of the non-classificatory and not compartmentalizable ownerless mens versus rabbinic equally ownerless mereological body, indeed flesh, of collective and subjectless unfolding of thinking and living in the mutually suspending efforts to remember, which can be neither recalled nor forgotten. That, however, extends beyond the scope of this essay.

\section{References}

Alter, Robert. 1996. Genesis: Translation and Commentary. New York and London: W.W. Norton \& Co.

Aronowicz, Annette, Emmanuel Lévinas, and Emmanuel Levinas. 2019. Nine Talmudic Readings. Bloomington: Indiana University Press, p. 164.

De Libera, Alain. 2011. From structure to rhizome: Transdisciplinarity in French thought (2). Radical Philosophy 167: 15-23.

De Libera, Alain. 2015. L'invention du sujet moderne: Cours du Collège de France 2013-2014 (Bibliotheque D'Histoire de la Philosophie), French ed. Paris: Librairie philosophique J. Vrin.

Lapidot, Elad. 2021. Heidegger as Levinas's Guide to Judaism beyond Philosophy. Religions 12: 477. [CrossRef]

Llewelyn, John. 1991. Am I Obsessed by Bobby? (Humanism of the Other Animal). In Re-Reading Levinas. Edited by Robert Bernasconi and Simon Critchley. London: Bloomsbury Academic, pp. 234-46.

Margel, Serge. 2015. La Mémoire du Présent: Saint Augustin et L'économie Temporelle de L'image. Paris: Hermann.

Ricœur, Paul. 1984. Fondements de l'éthique. In Autres Temps. Les Cahiers du Christianisme Social. N³. pp. 61-71. Available online: https://www.persee.fr/doc/chris_0753-2776_1984_num_3_1_956 (accessed on 1 August 2021). 